\title{
Monitoring the Structural Deformation of Davutpasa Barrack by Using Geodetic Methods
}

\author{
Ercenk ATA, Ramazan Gürsel HOŞBAŞ, Atinc PIRTI
}

\begin{abstract}
One of the important indicators of developed societies, protect their history and transport them for future generations. Therefore, sustainable monitoring and determination present situations of the historical buildings are important for protection of them. Knowledge and awareness of these structures in terms of absolute positional and dimensional information acquisition, evaluation and analysis associated with geomatic engineering. In this context, it is aimed to monitor the existing structural deformations of barrack located in Davutpasa Campus at Yildiz Technical University, for two hundred years, using modern geodetic techniques. In this study, geodetic network, has fixed and dynamic points, established to monitor horizontal and vertical deformations occurred in the southern-east facade of barrack. Mentioned network consists of 5 reference points and 10 traverse points. Six of polygons inside of the structure and the remaining 4 polygons are out of it. The structure has 54 object points, 28 of them are based inside the structure and the remaining 26 object point of them out of it. These points are based in a form of on the wall to determine the deviations from vertical plane and also the points in a form of a pair of points are based on the wall with same vertical direction. Since the date of June 2011, the structure measured for three periods by terrestrial and satellite observation techniques. The displacements observed during three periods of measurement. Horizontal positions of 5 fixed points are measured by satellite observation techniques. Also terrestrial measurements were made depending on 5 fixed points as mentioned above to determine the 10 polygon point's horizontal position. Horizontal positions of the object points are measured by distancelangle surveying technique and calculate their coordinates with resection method depend on polygons. Vertical displacement of 15 fixed points measured by precise geometric levelling method and horizontal displacement of 54 object points measured by precise trigonometric method. In this study, design of geodetic control network, measurements, evaluation and analysis first results are given.
\end{abstract}

Keywords: analysis; deformation; geodetic surveying methods; historical buildings

\section{THE HISTORY AND STRUCTURAL PROPERTIES OF DAVUTPASA BARRACKS}

Davutpasa Barracks is located on a hill above the old way linking Istanbul to Edirne. The military settlement dating back to the Byzantine period, which was to serve the military and the palace ceremony and is said to have named the region's Aretai. It is said that the pavilion of Sultan Mehmet II was established and the Ottoman Army stayed here during the conquest of Istanbul. It is believed that Davutpasa was constructed a wooden pavilion in this region in 1482. For establishing a new Asakir-I Mansure-I Muhammediye army in 1826, the barracks of Rami, Maltepe and Davutpasa were built. It is estimated that Amira Kirkor Balyan was the architect of the Davutpasa Barrack which have been built probably between 18261827 and 1831-1832 (Fig. 1). The barrack was destroyed during the Balkan Wars in 1912-1913 years and used for the accommodation of immigrants. During the First World War in 1914 a military hospital was opened and was closed in 1920. Until 1999, the structure was used by the Turkish Armed Forces as the military barracks and it was transferred to Ylldiz Technical University participated in providing educational services between the barracks $[1,9]$.

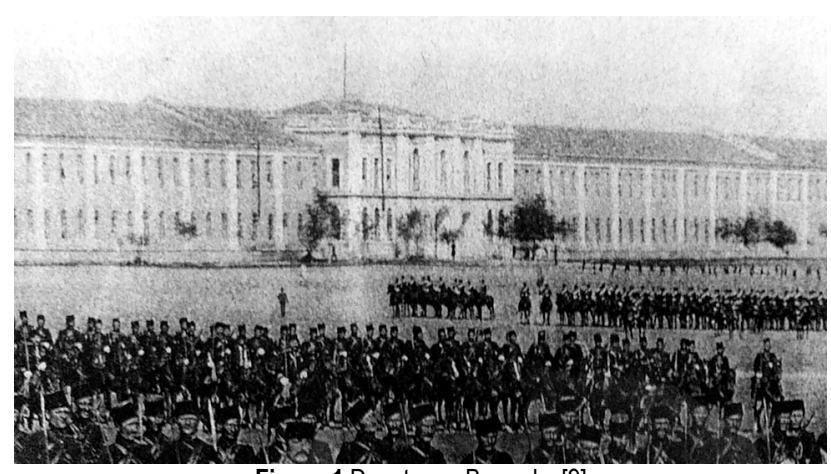

Figure 1 Davutpasa Barracks [9]
Davutpaşa Barracks is located on the highest elevation of the Davutpasa region (about $78 \mathrm{~m}$ ). Construction consists of three arms; one arm has a length of $362 \mathrm{~m}$, the other two arms equal, and one arm has a length of $187.5 \mathrm{~m}$ (Fig. 1). Long sections are located south-west/north-eastern direction. Building consists of hallway and the ward rooms. The barracks have two floors including the ground floor and first floor. Today the facade is covered with plaster. Masonry-built barracks in plaster was poured into alternating stone walls despite the existence of some surface indoors filling bricks have been used in some places. The thickness of wall is between 0.6 $\mathrm{m}$ and $1.30 \mathrm{~m}[1,9]$.

\section{GEODETIC CONTROL NETWORK AND MEASUREMENTS}

The intense deformation of the Davutpasa barracks is observed towards the south-east part. For this reason the geodetic control network is formed in this part. The network consists of the fifteen fixed points and the fiftyfour object points (Fig. 2). Five of the reference points are selected at suitable places for positioning with GPS (Fig. 3). Point number of 5003 and 5004 are located in the courtyard of the Davutpasa Barracks as triangulation points. Other reference points are selected on the concrete floor. The coordinates of these reference points (starting with 3000) were obtained by traversing using 5003 and 5004 points. The marks of these points are given in the form of bronze nails (Fig. 4). The object points in the corridor were selected between the upper and lower parts of the windows overlooking the courtyard. The object points on the south-east of barracks exterior are determined in the lower right corner of windows in the first floor and middle floor (Fig. 5). Starting with point 1000 in the object points are used foil prism (Fig. 6) [2, 3, $4,6,7,8]$. 


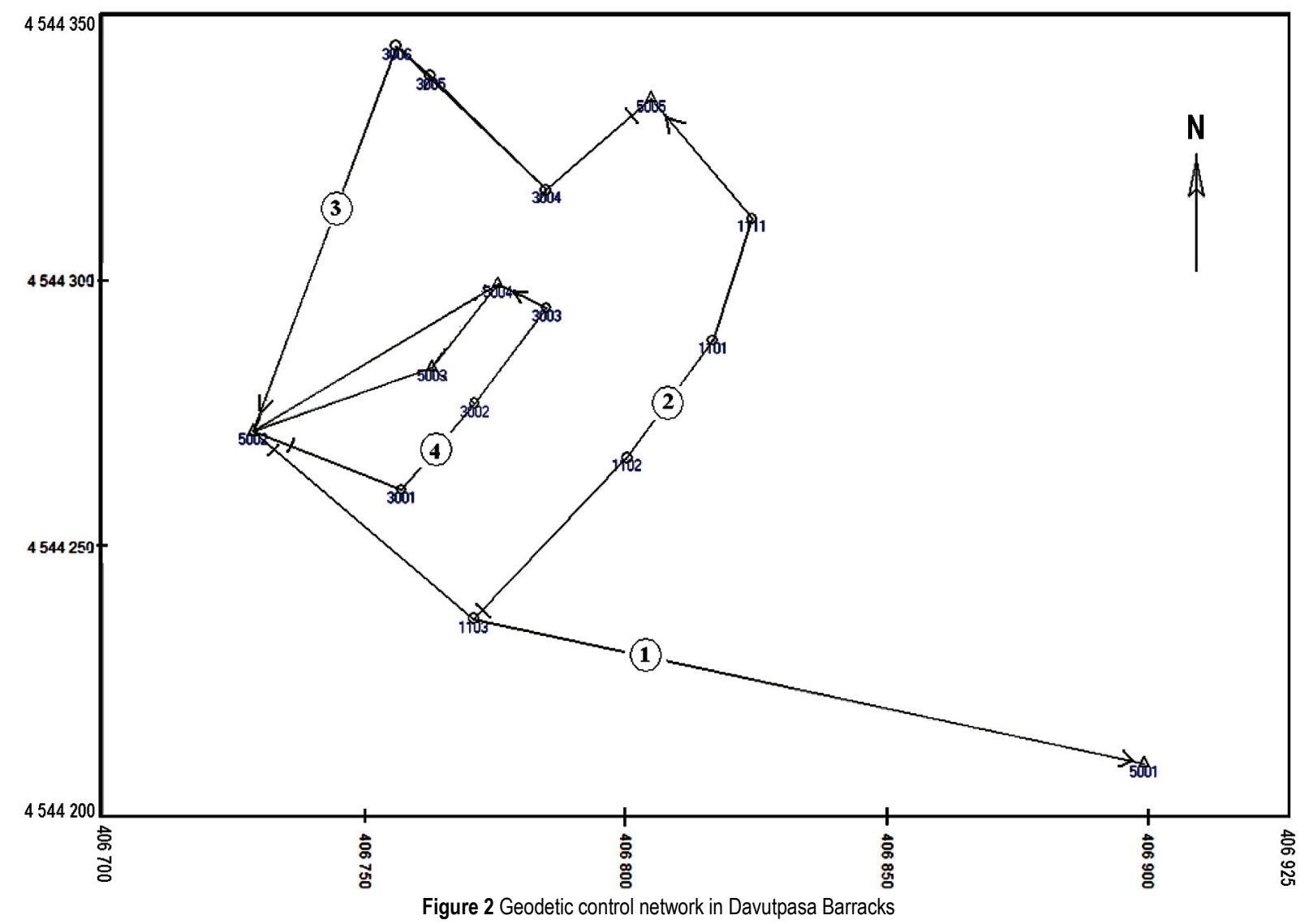

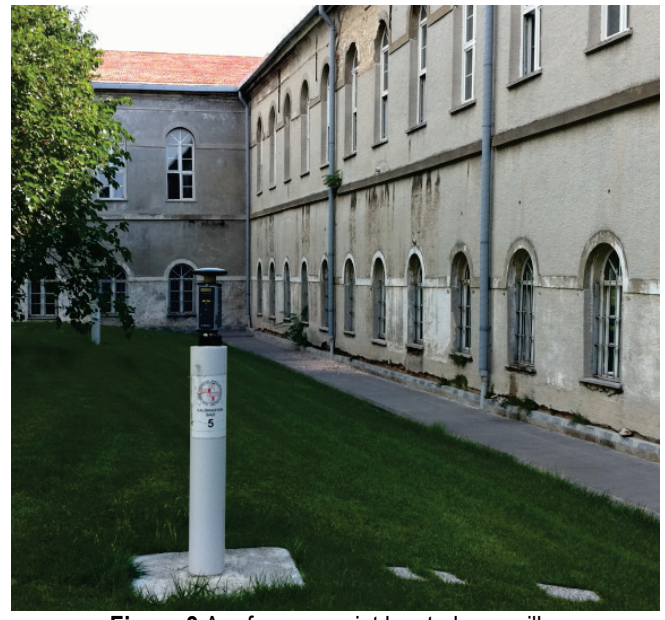

Figure $3 \mathrm{~A}$ reference point located as a pillar

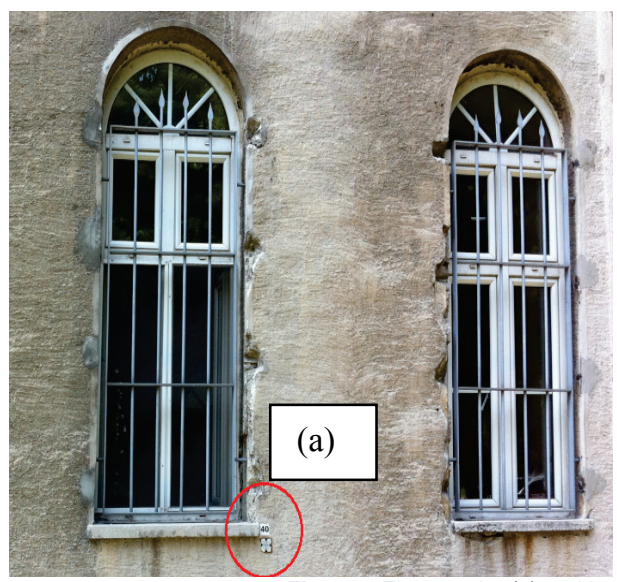

Figure 5 The exterior (a) and interior (b) object points of the building

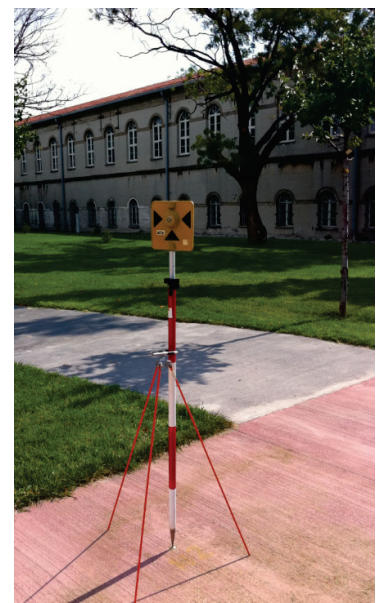

Figure $4 \mathrm{~A}$ reference point located as a bronze nail

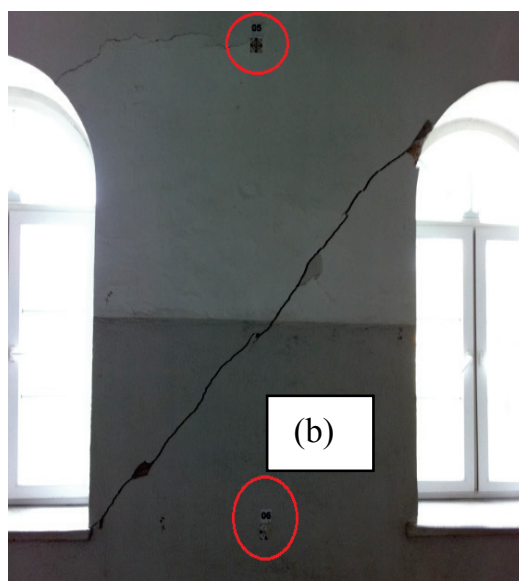

(b) 


\begin{tabular}{|c|c|c|c|c|}
\hline \multirow{2}{*}{$\begin{array}{l}\text { Measurements } \\
\text { group }\end{array}$} & \multicolumn{3}{|c|}{$\begin{array}{l}\text { The number of measurements } \\
\text { in the periods }\end{array}$} & \multirow{2}{*}{ Instructions } \\
\hline & June 2011 & $\begin{array}{c}\text { December } \\
2011\end{array}$ & June 2012 & \\
\hline Horizontal angle measurements & 122 & 103 & 107 & \multirow{5}{*}{$\begin{array}{l}\text { The measurement period in June 2011: } \\
\text { Instrument was set up } 13 \text { points (excluding } 5001,5003 \text { and } \\
5004 \text { points) } \\
\text { The measurement period in December } 2011 \text { : } \\
\text { Instrument was set up } 14 \text { points (excluding } 5001 \text { point) } \\
\text { The measurement period in June 2012: } \\
\text { Instrument was set up } 14 \text { points (excluding } 5001 \text { point) } \\
\text { All measurement periods: } \\
\text { The network consists of } 14 \text { points }\end{array}$} \\
\hline Slope distance measurements & 122 & 103 & 107 & \\
\hline Vertical angle measurements & 122 & 103 & 107 & \\
\hline Precise levelling measurements & 36 & 32 & 38 & \\
\hline Base vectors measurements & 9 & - & 3 & \\
\hline
\end{tabular}

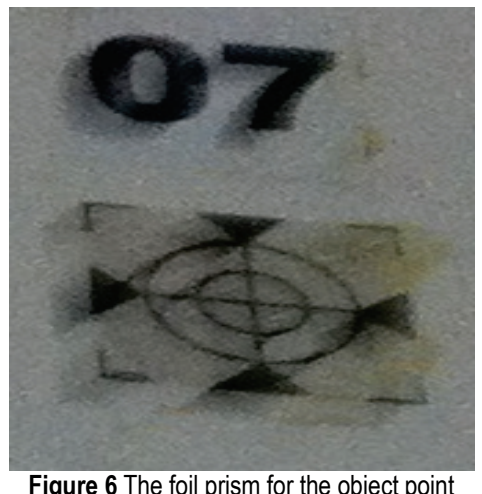

Geodetic control network was observed by using three measurements period. The first measurements were carried out in June 2011. The second and third measurements were performed at six monthly intervals. Some information regarding the measurement periods are shown in Tab. 1 [2].

The terrestrial measurements were performed by using Leica TCRA 1201 ATR Robotic Total Station
(Angle measurements with four sets and distance measurements with four times). The heights of instrument and reflector measurements were performed in $\mathrm{mm}$ level precision (Tab. 2). The surveying of the precise levelling was performed with using Leica DNA03 digital precise level and Leica GPCL2 barcode rod [2, 5].

GPS measurements were carried out by using five Thales $Z$ max GPS receivers in the long-term observations. In each of the five ground control points forming a large loop, GPS observations were performed a minimum of 3 hours. Five of ground control points (reference points) in high-precision coordinates were calculated by using ISKI-CORS GNSS stations in Istanbul.

Two loops, consisting of reference points (as closed levelling), were established for the network of the geometric levelling and were measured. Large loop consists of the points by using GPS, small loop consists of the points inside the barracks courtyard, corridor and on the south-east facade $[2,7,8]$.

Table 2 The precision of the observations in the measurements periods

\begin{tabular}{|l|c|c|c|}
\hline \multirow{2}{*}{\begin{tabular}{c} 
The group of the measurements \\
\cline { 2 - 4 }
\end{tabular}} & June 2011 & $\begin{array}{c}\text { December } \\
2011\end{array}$ & June 2012 \\
\hline Horizontal angle measurements $s_{\mathrm{r}}(\mathrm{cc})$ & 1.86 & 1.46 & 1.67 \\
\hline Vertical angle measurements $s_{\mathrm{z}}(\mathrm{cc})$ & 4.07 & 3.70 & 3.58 \\
\hline Precise trigonometric levelling $s_{\mathrm{th}}(\mathrm{mm})$ & 0.34 & 0.35 & 0.37 \\
\hline Precise geometric levelling $s_{\mathrm{gh}}(\mathrm{mm})$ & 0.40 & 0.21 & 0.05 \\
\hline
\end{tabular}

\section{EVALUATION OF THE DEFORMATION MEASUREMENTS}

Also the values of the vertical angles and slope distances are reduced to compute the heights of the object points by using trigonometric levelling. The height differences were calculated by using these values. The computation of the height differences was performed by using the earth curvature and refraction effects $[2,5]$. The precision values of the observations seem to be close to each other in June 2011, December 2011 and June 2012, see Tab. 3. Accordingly, the average standard deviation values for the measurements were obtained.

The coordinates of the reference points (start with points 5000, 5001, 5002, etc.) in the project area were calculated by using GNSS system and in ED 50 datum. The coordinates of the other reference points were calculated by means of the closed traverse. The coordinates of the object points were established by means of the intersection depending on the measurements of the directions and distances. And then the control network was adjusted by the free adjustment method [2].

Table 3 The average standard deviation values for the measurements were obtained

\begin{tabular}{|l|c|}
\hline \multicolumn{1}{|c|}{ The group of the measurements } & $\begin{array}{c}\text { The average std. } \\
\text { values }\end{array}$ \\
\hline Horizontal angle measurements $s_{\mathrm{r}}(\mathrm{cc})$ & 1.7 \\
\hline Vertical angle measurements $s_{\mathrm{z}}(\mathrm{cc})$ & 3.8 \\
\hline Precise trigonometric levelling $s_{\mathrm{th}}(\mathrm{mm})$ & 0.35 \\
\hline Precise geometric levelling $s_{\mathrm{gh}}(\mathrm{mm})$ & 0.22 \\
\hline
\end{tabular}

For determination of the height of the control points in the network a point height $(79.160 \mathrm{~m})$ locating on the right side of the main entrance of the military barracks. The network of levelling was adjusted by the unconfined adjustment method. 

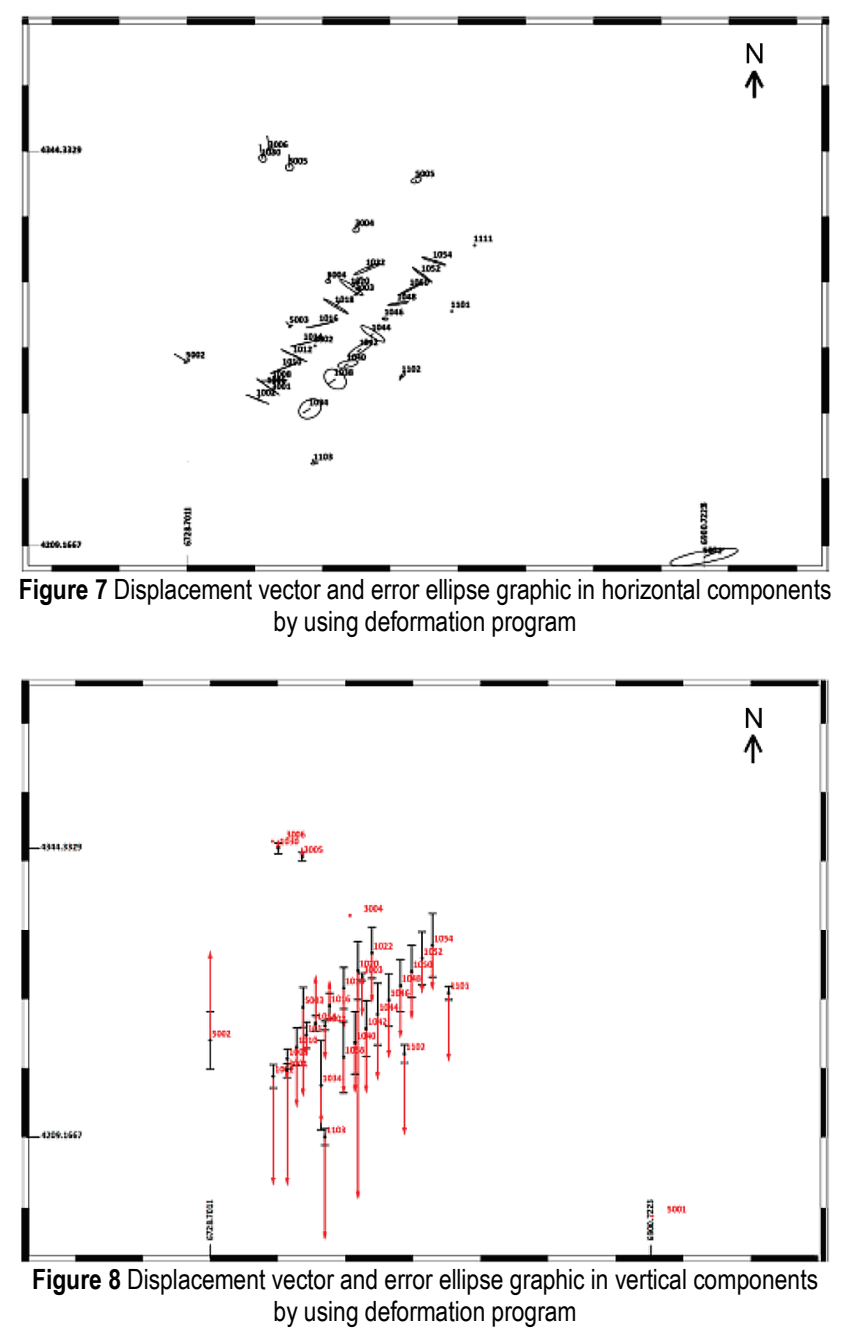

During the period 2011-2012, which is deemed suitable for the analysis of deformations, it was displaced 6-7 $\mathrm{mm}$ in the horizontal direction of the structure; While it was observed that it was sitting about $1 \mathrm{~cm}$ in the vertical direction in the same period (Figs. 7 and 8).

Despite all the negativities encountered during the monitoring of the historical Davutpasa building movements, it has been concluded that it is possible to determine the structural deformations in historical buildings with an accuracy of $\mathrm{mm}$ by creating an automation system through the use of modern measuring equipment and software developed by evaluating the data.

\section{CONCLUSION}

Historic buildings which made by our ancestors and have been entrusted to us to transfer future generation are cultural assets. The detecting for the building is used by geodetic measurement methods. During the period of three measurements were performed by using geodetic observations, given the size of the changes in millimetre can be determined easily seen.

Purpose of the study of the structure of the barracks

- Further information can be gained about the structure of the ground,

- Properly maintain their geometric structure and cannot change the temporal dimension can be determined,
- Protection and renovation measures should be performed in the future.

\section{REFERENCES}

[1] Doran, B., Kaya, E., Kütan, C., \& Koçak, A. (2012). Seismic analysis of a historical monument: Davutpasa Barracks. PLSE 2012 Proceedings PLSE First International Conference on Performance-based and Life-cycle Structural Engineering.

[2] Erkaya, H., Hoşbaş, G., \& Gülal, E. (2002). Deformation Measurement in Historical Buildings, Tarihi Yapilarda Deformasyon Ölçmeleri. Selçuk Üniversitesi Jeodezi ve Fotogrametri Mühendisliği Eğitiminde, 30. Y11, 17-18 Ekim, Konya.

[3] Hoşbaş, R. G. (1992). Baraj Deformasyonlarının Belirlenmesinde Jeodezik Yaklaşımların İrdelenmesi ve Bir Öneri, Doktora Tezi, YTÜ Fen Bilimleri Enstitüsü, İstanbul.

[4] Hoşbaş, R. G. (2010). Deformasyon Ölçmeleri (Basılmamış Ders Notları), YTÜ İnşaat Fakültesi Harita Mühendisliği Bölümü, İstanbul.

[5] Miguel, P., Luis, B., Manuel, Paez, R., Alberto, F. R., \& Amos, D. G. (2012). IESID: Automatic system for monitoring ground deformation on the Deception Island volcano (Antarctica). Computers \& Geosclences, 48, 126133. https://doi.org/10.1016/j.cageo.2012.05.004

[6] Rueger, J. M. (2006). Overview of Geodetic Deformation Measurements of Dams. Australian Committee on Large Dams. (ANCOLD) Technical Proceedings 2006, Australian Committee on Large Dams (ANCOLD), Conference on Dams, Instrumentation and Survey Seminar, Sydney, 20-22 November, 1-34. http://www.gmat.unsw.edu.au/snap/ publications/rueger_2006a.pdf.

[7] Stepniak, K., Baryla, R., Wielgosz, P. et al. (2013). Optimal data processing strategy in precise GPS levelling networks. Acta Geodynamica et Geomaterialia, 10(4), 443-452. https://doi.org/10.13168/AGG.2013.0044

[8] Verma, M. \& Bansal, B. K. (2012). Indian national GNSS programme: crustal Deformation Measurements. The Indian Sub-Continent Journal of Asian Earth Sciences, 50, 1-6.

[9] Davutpasa Barrack in History, http://akbelediye.com/arsiv/ 6-tarihte-davutpaa-klas, 14.05.2013.

\section{Contact information:}

Ercenk ATA, Associate Professor Dr

Yildiz Technical University, Faculty of Civil Engineering,

Department of Surveying Engineering

Davutpaşa, Istanbul - Türkiye

Contact Tel: +902123835303

E-mail: ata@yildiz.edu.tr

Ramazan Gürsel HOŞBAŞ, Assistant Professor Dr.

Yildiz Technical University, Faculty of Civil Engineering,

Department of Surveying Engineering

Davutpaşa, Istanbul - Türkiye

Contact Tel: +90212 3835299

E-mail: ghosbas@yildiz.edu.tr

Atinc PIRTI, Professor Dr

Yildiz Technical University, Faculty of Civil Engineering,

Department of Surveying Engineering

Davutpaşa, Istanbul - Türkiye

Contact Tel: +902123835303

E-mail: atinc@yildiz.edu.tr 